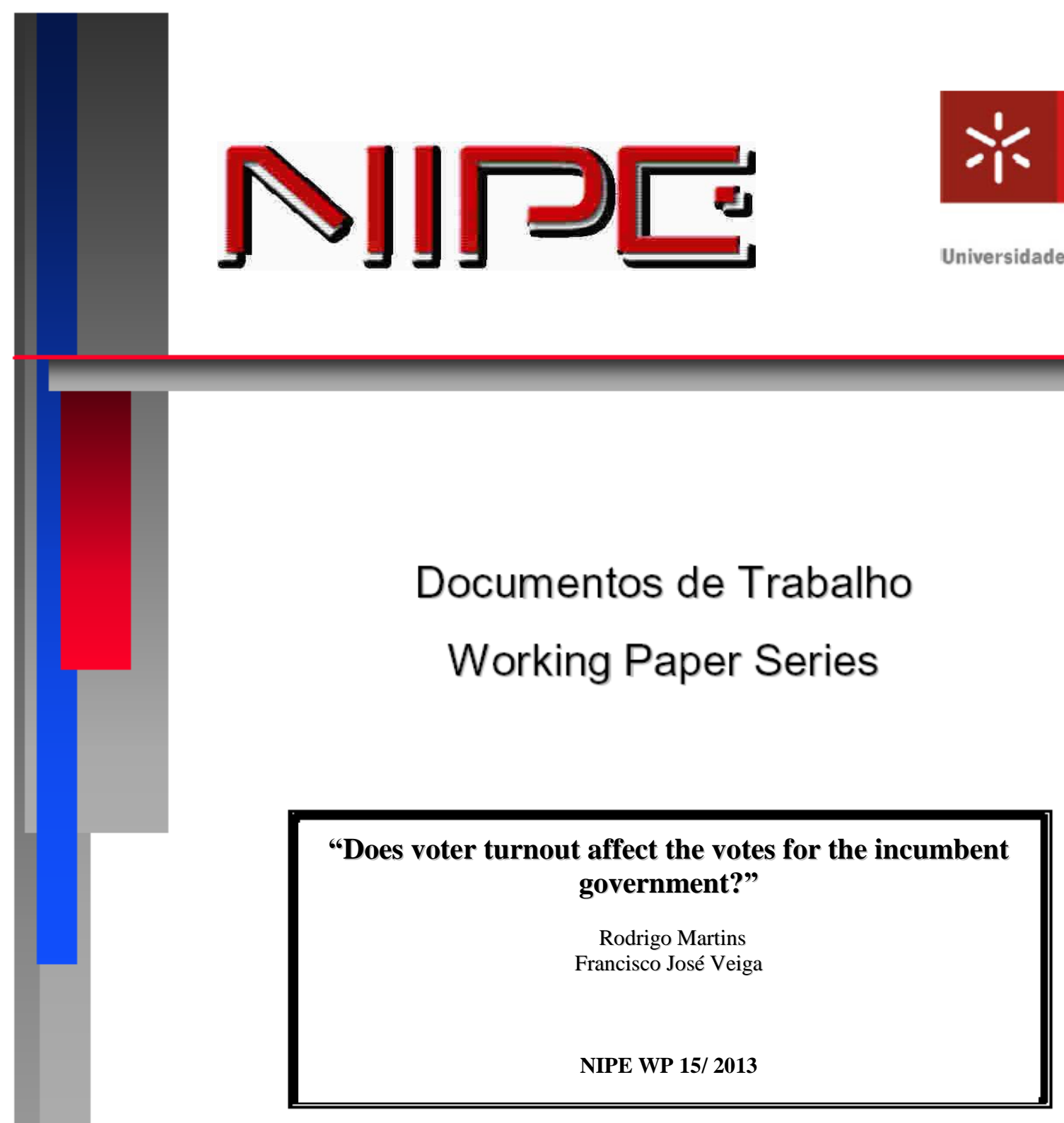

NÚCLEO DE INVESTIGAÇÃO EM POLÍTICAS ECONÓMICAS UNIVERSIDADE DO MINHO 


\section{"Does voter turnout affect the votes for the incumbent government?"}

Rodrigo Martins

Francisco José Veiga

NIPE* WP 15/ 2013

URL:

http://www.eeg.uminho.pt/economia/nipe
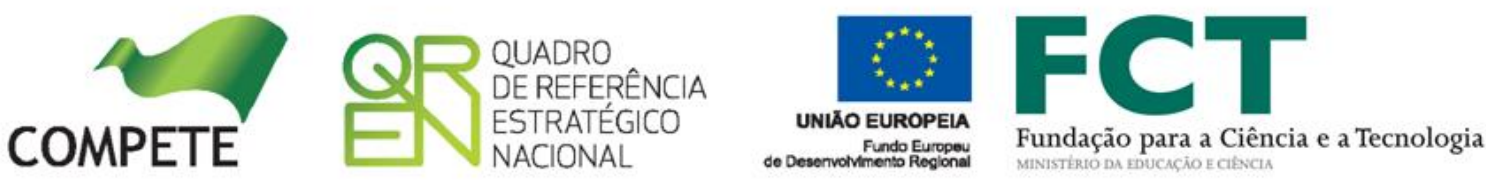


\title{
Does voter turnout affect the votes for the incumbent government?
}

\author{
Rodrigo Martins ${ }^{\mathrm{a}}$ \\ Universidade de Coimbra and GEMF \\ Francisco José Veiga ${ }^{b}$ \\ Universidade do Minho and NIPE
}

\begin{abstract}
This paper analyzes the effects of voter turnout on the vote shares received by the incumbent government. A system of simultaneous equations is estimated using a panel dataset of 278 Portuguese municipalities, for the period 1979-2005, covering 10 legislative elections. The results indicate that right-wing governments have lower vote shares when turnout is higher, while left-wing ones seem to be unaffected. There is also evidence of the responsibility hypothesis, that turnout is higher in closer elections, and that regional/local economic variables have non-linear effects on turnout.
\end{abstract}

Keywords: Vote shares; Turnout; Legislative Elections; Portugal.

JEL Classifications: D72, H7.

THIS VERSION: September 2013

\footnotetext{
${ }^{a}$ Faculdade de Economia, Universidade de Coimbra, Av. Dias da Silva 165, 3004-512 Coimbra, Portugal. E-mail: rodrigom@fe.uc.pt.

${ }^{b}$ Corresponding author: Francisco José Veiga, Escola de Economia e Gestão, Universidade do Minho, 4710-057 Braga, Portugal. E-mail: fjveiga@eeg.uminho.pt.
} 


\section{Introduction}

This paper addresses the issue of whether turnout matters for the outcome of the political process, namely if it has some influence in determining the electoral results of incumbent governments. Implicitly, most studies assume that the preferences of nonvoters match those of actual voters and, therefore, turnout variations have no impact on electoral results. This hypothesis is debatable, as the reasons to cast a vote are not necessarily coincident with those that lead voters to choose a given party. On the one side we have an extensive literature that studies the voting choice between political alternatives. In the fields of economics and of political science this subject has been extensively researched, mainly through empirical analyses of governments' vote/popularity (VP) functions. On the other side, the decision to vote or not has been a major topic of interest for those that study the democratic process, especially because turnout rates have been declining over time in most countries.

The literature that combines both turnout and voting choices has mainly been concerned with non-voters' partisan orientations, and, consequently, with the understanding of the potential impact of turnout fluctuations on party vote. Surprisingly, minimal attention has been devoted to the analysis of turnout effects on government vote shares. This raises some concerns, namely the possibility that empirical VP functions are consistently failing to capture the full scope of economic and political effects, and that they may be producing biased results. This is especially true if the economy affects both the decision of whether to vote and how to vote. Several studies show this to be the case ${ }^{1}$ and so the most reasonable course of action is to regard turnout as an intervening variable in the VP function. If voters reward/punish governments, there is no reason to think that nonvoters, or at least some of them, do not use similar mechanisms to decide whether to vote or not. Consequently, their decisions will affect the electoral results of the incumbent party. Whether this effect actually exists and has enough influence to be a major determinant of the electoral failure/success of governments is, as yet, an unanswered question. Furthermore, the study of nonvoters' partisan preferences probably should start

\footnotetext{
${ }^{1}$ On the effects of the economy on votes, see the surveys by Paldam (2004) and Nannestad and Paldam (1994). On turnout, see the surveys by Blais (2006) and Geys (2006). Regarding the Portuguese case, Veiga and Veiga (2010), among others, show that economic performance affects the votes received by the incumbent government, and Martins and Veiga (2013) show that turnout also reacts to the state of the economy.
} 
within the VP function. If turnout does not influence the incumbents' VP function or it affects all governments' in a similar way regardless of their ideological orientation, then the most likely scenario is to reach similar conclusions when studying party functions, as VP functions are well-suited to capture some key dimensions that arise when trying to link turnout with party vote.

Estimating a system of equations over an extensive panel dataset for the results at the municipal level of Portuguese legislative elections from 1979 to 2005, we find robust empirical evidence indicating that an increase in turnout reduces the vote shares of the incumbent national government when partisan effects are taken into account, there is evidence that right-wing incumbents are negatively affected by high turnout, while left-wing governments are not. Additionally, the economic dimension still remains an important factor in the VP function after controlling for turnout effects. Finally, the national and regional/local economies affect turnout.

The rest of the article is organized as follows. Section 2 discusses the relationship between turnout and the vote. Section 3 describes the empirical model and dataset used. The panel data results are presented and discussed in section 4, and section 5 concludes.

\section{Turnout and Government electoral results}

Voter turnout is one of democracy's outcomes that has been more carefully studied, and various theories have emerged addressing the many different aspects of the theme (see Geys 2006 and Blais 2006 for encompassing surveys). As it stands, the existing research has established some robust patterns. Sociological characteristics, especially age and education, have been consistently referenced as important explanatory factors (see, among others, Blais 2000 and Franklin 2004). We also know relatively well why turnout is higher in some countries than in others. Comparative studies highlight, as explanatory sources for these dissimilarities, the different institutional arrangements and electoral laws and in general, the more accountable and competitive the political systems are, the larger the electoral mobilization is (see Powell 1986, Jackman 1987, and Jackman and Miller 1995). However, concerning the economic dimension we find two compelling theories, one claiming that adverse 
economic conditions foster turnout, while the other defends the opposite effect. On this subject the empirical literature provides mixed results and is far from reaching a consensus ${ }^{2}$.

The determinants of governments' electoral fortunes have been a major topic of interest especially for scholars that study the influence of economic conditions on the democratic process, and the most common approach to the subject has been the empirical analysis of governments' vote/popularity (VP) functions. Traditional VP functions include two major groups of variables: economic and political. Overall, it seems uncontroversial that there are costs of ruling, meaning that governments' lose popularity over time, although this does not mean they always lose elections. The literature also consistently finds that the economy matters, especially inflation and unemployment, and that voters react to the economic environment as predicted by the responsibility hypothesis (see Paldam 2004 and Nannestad and Paldam 1994).

Traditionally, the subject of voter turnout and the study of governments' electoral results have been empirically treated independently, even though they are determined by the same process, and in the theoretical voting models based on the works of Downs (1957) and Riker and Ordeshook (1968) we find both decisions depicted in one single equation.

Traditional government vote functions implicitly assume that one of the key questions on the elector's mind is whether to vote or not for the government. With this binary choice the stand-alone equation of government voting is appropriate, as it is reasonable to assume that the most logical choice when voting against the government is to support the party that is best prepared to overthrow it. However, abstention is also an option, and the literature has chosen to ignore this third choice, maybe because of methodological difficulties associated with the inclusion of the nonvoters' share. Nevertheless, there is little doubt that a system that includes all three choices is closer to reality than the customary approach. Lavernier (1992) tests the influence of economic conditions on voter participation rates and on electoral outcomes in gubernatorial elections, modeling voting as a two-stage process where an individual first decides whether or not to vote and only afterwards determines which candidate to support. He concludes that the outcomes of gubernatorial elections are mainly determined by non-economic factors and only finds weak evidence supporting the relevance of economic variables. Likewise, Lacy and Burden (1999) include abstention as a

\footnotetext{
${ }^{2}$ See Martins and Veiga (2013) for a more detailed discussion.
} 
choice in voting models, highlighting the impact of Perot's candidacy on turnout and on the other presidential contestants' electoral results. Bengtsson (2004) argues that turnout variations can actually affect the importance of economic variables in the VP function and his results show that in elections with decreasing turnout rates the economy vanishes from the governments' vote function, resurfacing again in elections with stable or increasing turnout.

In the literature that links the two electoral decisions, clearly the topic that has been more closely scrutinized is the partisan consequences of low turnout. DeNardo (1980) identifies an important effect that can explain the impact (if any) of turnout on party vote: increased turnout helps the party with the larger reserve of habitual nonvoters. Popular wisdom considers that left-wing parties' supporters dominate in this category as these consistent abstainers tend to be, broadly speaking, lower status citizens that are more likely to prefer parties on the left (Lijphart 1997). There is some cross-national empirical support for this idea. For instance, Pacek and Radcliff (1995) find that across 19 democracies, a one percent increase in turnout increases on average the vote share of left parties by nearly one-third of a percentage point, while Bohrer et al. (2000), working on a panel of postcommunist countries, estimate nearly a one percent effect of turnout on these parties' electoral outcomes. Nevertheless the majority of the literature has been unable to find solid evidence of this relationship, and Lutz and Marsh (2007) conclude that turnout probably does not matter a great deal ${ }^{3}$.

It is reasonable to assume that occasional voters tend to be unreliable partisans (or they simply do not identify themselves with any of the existing parties) and thus are more easily motivated by short term considerations. If so, habitual nonvoters, or at least some of them, probably rely on a non-partisan view of electoral alternatives. Consequently, the electoral choice may be between voting for or against the government. Grofman et al. (1999) point out the existence of a competition effect, claiming that high turnout is more likely to occur when the contest is close. A decrease in the government's popularity raises the number of voters wanting to dislodge it from power; therefore, those that decide to leave the nonvoters' ranks tend to vote against the government. If voters' tendencies to punish governments exceed the motivation to reward them ("negative voting" theory, see Lau

\footnotetext{
${ }^{3}$ See also Zimmer (1985) and Tucker and Vedlitz (1986).
} 
1982) then one should expect the effect to be greater in situations of severe economic hardships. Short term political and economic conditions can play a major role in shifting partisan preferences of nonvoters. Therefore, one obvious conclusion is that the reward/punishment mechanism and other factors identified in governments' voting functions, such as the costs of ruling, may have indirect effects on the VP function that comes from turnout variations.

There is no reason to think that the partisan bias effect, and the competition effect cannot occur simultaneously and the way these forces combine is important to understand the role of turnout on governments' vote functions. Clearly, these effects work against each other when left-wing parties are incumbents, and exhibit the same direction when rightwing parties are in office, therefore only a leftist party in the opposition should experience a positive effect from both sources This means that a minimum requirement for nonvoters to actually be more prone to vote for left-wing parties is that the governments' VP function shows systematical differences in the impact of turnout that work in favor of left-wing governments when compared to other incumbents. Table 1 summarizes the different possible scenarios that can be found in the VP function for which the traditional partisan bias claim can hold, when considering multiparty systems.

\section{[INSERT TABLE 1 ABOUT HERE]}

In sum, right-wing incumbents' electoral results must not be positively impacted by higher turnout and the effect on the left-wing governments' vote shares determines our perception of the hypothetical existence and magnitude of both the responsibility hypothesis and the partisan bias effect. The last scenario in Table 1, where no effect is found for the right and a positive one is found for the left, is a rather strange possibility, with no evidence of the competition effect and with what we call a partisan bias with asymmetric response effect. In this case, nonvoters are leftist but do not seem to care about right-wing governments, they only reward or punish left governments. As for the other possible scenarios missing in Table 1 (when the right has a positive competition effect), they either refute the existence of both effects or negate the competition effect and posit that frequent abstainers are more sympathetic towards the right-wing parties. 


\section{The data}

In order to investigate the relationship between turnout and the incumbent government's vote shares we estimate a system of simultaneous equations over an extensive dataset comprised of panel data for all mainland Portuguese municipalities ${ }^{4}$ (currently 278), ranging from 1979 to 2005 and covering 10 legislative elections. Electoral results and political data used were all obtained from the National Elections Commission (Comissão Nacional de Eleições - CNE). Demographic data were obtained from the local authority's (Direcção Geral das Autarquias Locais - DGAL) annual publication called Finanças Municipais (Municipal Finances) and from the Portuguese National Institute of Statistics (Instituto Nacional de Estatísticas - INE). ${ }^{5}$

An ample set of economic variables was assembled in order to capture both national and the local economic conditions. The national unemployment rate was obtained from the OECD's Main Economic Indicators, while the inflation rate and the national GDP were acquired from the IMF's International Financial Statistics. Data for regional GDP and unemployment rates (both at the NUTS $\mathrm{II}^{6}$ level) were obtained from INE. The regional NUTS III unemployment rate was available only for 1991 and from 1999 onwards, thus reducing time variability and the number of observations in our sample. To circumvent this scenario, we estimated a proxy for the unemployment rate for the remaining years of the 1990's using the multiple imputation algorithm developed by Honaker and King $(2010)^{7}$. Unfortunately, there are no consistent time series data for unemployment available at the municipal level. However, in order to have some labor market data at the municipal level, we use employment in private firms seeded in each municipality, which is available on the

\footnotetext{
${ }^{4}$ Mainland Portugal is divided into 18 districts and each district contains several municipalities. Overall there are 278 municipalities (municípios or concelhos).

${ }^{5}$ The data on the percentage of the population in the tertiary sector were obtained from the Census operation of INE. Data were available for 1981, 1991 and 2001. As the evolution of this type of variable is generally based on a stable trend, a constant growth rate was assumed to fill in the missing data. Data on population by age (also from INE) was obtained by assuming a constant growth rate for the period 1979-1989, on the basis of the 1970 and 1981 census; for the remaining years annual data was acquired from INE's resident population estimates.

${ }^{6}$ NUTS is a geocode standard for referencing the subdivisions of countries for statistical purposes, used within the European Union. In Portugal, a hierarchy of three NUTS levels is established. Continental Portugal corresponds to a NUTS I region, which is subdivided into 5 NUTS II regions. These 5 regions are then subdivided into 28 sub regions (NUTS III) each one comprised of several municipalities.

${ }^{7}$ This method is a bootstrapping-based algorithm particularly suited to tackle the problem of missing data in panel data when $t<n$. It extracts relevant information from the observed portions of a data set via a statistical model that includes a set of explanatory variables. This method was not used to solve the missing data problem with our demographic variables because there were too many missing values.
} 
"Quadros de Pessoal" database of the Portuguese Ministry of Solidarity and Social Security (MSSS). ${ }^{8}$ Also from this source, we use data on the average municipal real wage growth rate, available since 1985. As proxies of municipal income and purchasing power we use three indexes from the Marktest's Sales Index database: the Income index, the Fiscal burden index, and the Sales index. ${ }^{9}$ Descriptive statistics for all variables used in the estimations are shown in Table 2.

\section{[INSERT TABLE 2 ABOUT HERE]}

\section{Empirical model}

The hypotheses that turnout (Turn) affects votes for the incumbent government (GV) and that economic variables (Eco) affect both votes and turnout recommend the joint estimation of equations for vote shares and turnout. The structural form of the model can be written as follows:

$$
\begin{aligned}
& G V=g(\text { Turn, Eco, X) } \\
& \text { Turn }=h(E c O, Y)
\end{aligned}
$$

where $g$ and $h$ are functions and $X$ and $Y$ are (possibly overlapping) vectors of other determinants of government vote shares and turnout at legislative elections. The scenarios for the effects of turnout on vote shares were described in Table 1 . In the simplest specification, in which turnout is included in equation (1) without any interaction with partisan dummy variables, we expect a negative coefficient.

Based on the literature surveyed in the previous section, some exclusion restrictions are imposed on $g$ and $h$, so that we can empirically identify how vote shares and turnout are related. As economic variables affect vote shares and turnout, the vector Eco is included in both equations (although it does not have to be the same in both equations). The responsibility hypothesis suggests that favorable/adverse economic circumstances have positive/negative effects in the vote shares of the incumbent government. Then, according to Martins and Veiga (2013), favorable/adverse national economic circumstances

\footnotetext{
${ }^{8}$ This is a yearly mandatory employment survey that covers almost all privately owned firms employing paid labor in Portugal (public servants and own employment are not included).

9 The Income index reflects municipalities' incomes by accounting for the fiscal burden, electricity consumption, automobiles sales, and the number of banks and retail stores. The fiscal burden index combines national and municipal taxes paid in each municipality. Finally, the Sales Index reflects municipalities' purchasing power by considering a population index and the Income Index.
} 
decrease/increase turnout and regional/local economic variables have a quadratic effect on turnout. Regarding non-economic variables, we also include in both equations lags of the dependent variable, the population density as a measure of the municipalities' size, and a dummy variable (Same party as national) which takes the value of 1 when a local government is controlled by the party that holds power at the national level, and equals zero otherwise. Regarding the effects of the population density, we have no prior expectations concerning the coefficient in the vote shares equation, but we expect a negative effect in the turnout equation, as more populous and more densely populated areas usually register lower turnout rates. The dummy variable referred to above identifies those municipalities where the national governing party exhibits high vote shares at municipal elections. One should expect this strong political support to be reproduced in legislative elections, which implies a positive coefficient. Finally, time and electoral district specific effects are also expected to affect vote shares and turnout, and are thus also included in both equations.

The literature on voter turnout (see Blais 2006 and Geys 2006 for surveys) suggests that some additional variables should be included in equation (2). Regarding political variables, we use a standard measure of closeness of the elections, defined as the difference in vote shares between the winning party and its closest challenger at the district level (WinMargD), ${ }^{10}$ and also the Laakso and Taegepera (1979) index for the effective number of political parties, also district based. We expect a negative coefficient for the win margin, as greater values are associated with less competitive elections, which tend to be associated with lower turnout rates. Since both the theoretical and empirical literatures are inconclusive regarding the effects of party fragmentation on turnout (see Geys 2006), we have no prior concerning the sign of the coefficient associated with the effective number of parties. To control for the municipalities' socio-demographic characteristics, we include the the share of the resident population over 65 years old and the percentage of the

\footnotetext{
${ }^{10}$ Although the closeness of the election at the national level may affect turnout, the inclusion of an additional variable with no cross-sectional variation (like the national macroeconomic variables) may be problematic. Thus, we chose to include the winning margin at the district level. Since this is the level at which votes are transformed into seats in the Portuguese parliament, voters may actually realize that, independent of the national result, their votes are more likely to matter when there is a close election in their district. As a robustness test, we replaced the winning margin at the district level by the national winning margin. The results obtained regarding the effects of turnout on votes were practically the same, and the national winning margin had a negative coefficient in most of the estimations of the turnout equation. These results are not shown here, but are available from the authors upon request.
} 
municipality's population employed in the tertiary (services) sector. As these variables are not expected to directly affect the vote shares of the incumbent government, they are not included in vector $X$ of equation (1).

Given that the margin of victory at the district level (WinMargD), included in the turnout equation, is endogenous to the government's vote shares, we estimate a third equation, in which this variable is explained by the government vote share (GV), the margin of victory at the district level in the previous legislative elections, the margin of victory at the municipal level (WinMargM) in the previous elections and time and district effects.

The above discussion on exclusion restrictions implies the estimation of the following system of equations:

$$
\begin{aligned}
& G V_{i, E}=\alpha_{1} \text { Turn }_{i, E}+\alpha_{2} G V_{i, E-1}+\alpha_{3} E_{C O} O_{i, E}+\alpha_{4} X_{i, E}+\alpha_{5} \text { Election }_{i, E}+d_{i, E}+\varepsilon_{i, E} \\
& \text { Turn }_{i, E}=\beta_{1} \text { Turn }_{i, E-1}+\beta_{2} E_{C O}{ }_{i, E}+\beta_{3} Y_{i, E}+\beta_{4} \text { Election }_{i, E}+\beta_{5} \text { WinMargD }_{i, E-1}+d_{i, E}+\mu_{i, E} \\
& \text { WinMargD }_{i, E}=\lambda_{1} G V_{i, E}+\lambda_{2} \text { WinMargD }_{i, E-1}+\lambda_{3} \text { WinMargM }_{i, E-1}+\lambda_{4} \text { Election }_{i, E}+d_{i, E}+\xi_{i, E} \\
& i=1, \ldots, 278, E=1979,1980,1983,1985,1987,1991,1995,1999,2002,2005
\end{aligned}
$$

where $G V_{i, E}$ is the percentage of votes obtained in municipality $i$ by the national government party in legislative election $E$, Turn $_{i, E}$ is the percentage of registered voters in municipality $i$ which voted in legislative election $E, \operatorname{WinMarg}_{i, E}$ is the margin of victory in the district level municipality $i$ belongs to in election $E, E c O_{i, E}$ is a set of economic variables, $X_{i, E}$ and $Y_{i, E}$ are sets of non-economic variables, Election $_{i, E}$ is a discrete variable that indexes the elections from 1 to $10, d_{i, E}$ is a set of district dummies (the municipalities are grouped into 18 districts), $\alpha_{1}-\alpha_{5}, \beta_{1}-\beta_{4}$ and $\lambda_{1}-\lambda 5$ are parameters or vectors of parameters to be estimated, and $\varepsilon_{i, E}$ and $\mu_{i, E}$ are error terms. Since national economic variables do not have crosssectional variation, it is not possible to combine them with time dummy variables. Thus, time effects are accounted for with an election trend $\left(\right.$ Election $\left._{i, E}\right)$ which varies from 1 in the first election to 10 in the last (works like a time or election trend). Finally, since votes are transformed into seats at the district level, ${ }^{11}$ we control for district specific effects by including district dummy variables $\left(d_{i, E}\right)$.

The equations should not be estimated by Ordinary Least Squares (OLS), as their disturbances are correlated with the endogenous variables. Furthermore, as some of the

\footnotetext{
${ }^{11}$ In legislative elections, the territory of mainland Portugal is divided into 18 constituencies (one for each district), where political parties present ordered and closed lists of candidates. The number of deputies elected in each district is a function of its population. Votes are transformed into mandates using the D'Hondt method, which is a highest averages method for allocating seats in party-list proportional representation.
} 
explanatory variables in one equation are dependent variables of other equations, the error terms of the equations are expected to be correlated. Given these problems, the equations are estimated simultaneously by Three-Stage Least Squares (3SLS), which uses an instrumental variables approach to produce consistent estimates and Generalized Least Squares (GLS) to deal with the correlation of the disturbances across equations. ${ }^{12}$ In order to account for wide population differences across municipalities the respective numbers of registered voters are used as weights.

\section{Empirical results}

The results of the estimation of the system of equations when including economic variables only at the national level are shown in Table $3 .{ }^{13}$ In order to avoid simultaneity problems, especially when elections took place in the beginning of the year, the values of the economic variables considered in the estimations are those of the year before the elections. The results for vote shares indicate that, according to our expectations, higher turnout decreases the vote shares of incumbent governments.

\section{[INSERT TABLE 3 ABOUT HERE]}

Consistent with the responsibility hypothesis, higher inflation and unemployment reduce vote shares, while higher real GDP growth rates increase them. Thus, as in Veiga and Veiga (2010), there is evidence that Portuguese voters reward/punish governments for positive/negative economic outcomes. Concerning the remaining explanatory variables, lagged vote shares, population density and the election trend are negatively associated with current vote shares, while party similarity between the national and local governments is associated with higher vote shares.

Regarding the turnout equation, and in line with Martins and Veiga (2013), positive/negative economic outcomes are associated with lower/higher turnout, indicating that voters are more mobilized to vote (eventually, to penalize the incumbent government) in times of economic hardship. There is also evidence of persistence of turnout rates, that party similarity, higher percentage of the population in the tertiary sector and the election

\footnotetext{
${ }^{12}$ The system of equations is estimated using command reg3 of Stata version 12. For further information on the 3SLS method, see Zellner and Theil (1962) and Greene (2012, Chapter 10).

13 Data on regional/local economic variables starts in the mid-1980s, for some variables, and in the early 1990s, for others. Thus, in order to perform estimations for the full sample period of 1979-2005, we include only national economic variables in the estimations of Tables 3 and 4.
} 
trend are positively associated with turnout, and that population density, higher winning margin (smaller closeness of elections), and greater effective number of parties lead to lower turnout. These results are consistent with our expectations and with the results of previous studies. Finally, concerning the win-margin equation, ${ }^{14}$ higher government vote shares lead to greater winning margins, as one would expect, and greater win-margins at the district or municipal levels in the previous elections are associated with lower current winning margins.

In order to more completely analyze the effects of turnout on vote shares, in the estimations whose results are reported in Table 4, we interacted turnout with a dummy variable that takes the value of 1 for governments led by the Socialist Party (PS) and equals zero for governments led by the Social Democratic Party (PSD). Elected governments in Portugal since the Revolution of April 1974, which restored Democracy after 48 years of dictatorship, have been led by the Socialist Party (Partido Socialista - PS) or by the Social Democratic Party (Partido Social Democrata - PSD). Ideologically, PS can be classified as center-left and PSD as center-right. The average marginal effects of turnout on vote shares, depending on which party leads the national government, are reported in the Appendix.

\section{[INSERT TABLE 4 ABOUT HERE]}

For both estimations, the effects for PS governments are not statistically significant, indicating that left-wing governments do not tend to be affected by the turnout rate. The effects for right-wing governments are negative, highly statistically significant, and sizeable. The estimated marginal effects imply that a 1 percentage point increase in the turnout rate decreases the vote shares of right-wing (PSD) governments by 0.665 to 1.062 percentage points. Given the absence of turnout effects for left-wing governments and the negative effects for right-wing ones, we conclude that, of the scenarios described in Table 1, the one that best reflects the Portuguese experience is the second. Thus, there is some evidence of both the competition effect and of partisan bias. ${ }^{15}$

The estimated effect of PS governments on vote shares is calculated combining the estimated coefficients for the PS dummy with those for of its interaction with turnout

\footnotetext{
${ }^{14}$ Since our investigation primarily concerns vote shares and turnout, and there are no especially interesting hypotheses related to the estimation of the equation for the win margin (Equation 5), we chose not report its results in the following tables. Nevertheless, they are available from the authors upon request.

15 These results are also in line with the turnout model of Hortala-Vallve and Esteve-Volart (2011), which implies that moderate voters (most of the PS electorate) tend to vote less than voters who report to be either liberal or conservative (who tend to vote more for PSD).
} 
Overall, there is weak evidence of a positive effect, ${ }^{16}$ implying that PS governments tend to have larger vote shares than PSD governments. The results for the other explanatory variables are very similar to those reported in Table 2, implying that our previous conclusions remain valid.

Regional/municipal economic variables were included in the estimations whose results are shown in Table 5. Since a sufficiently long time series of municipal unemployment rates is not available, we use unemployment rates for the 28 NUTS III regions of mainland Portugal. The same was done for real GDP, as it is not available at the municipal level.

\section{[INSERT TABLE 5 ABOUT HERE]}

The results of estimations 1 and 2 indicate that higher regional unemployment reduces vote shares, while higher regional real GDP increases them. As with national economic variables, the effects on turnout have the opposite sign. Then, we included several municipal variables, such as the income and fiscal burden indexes, which are proxies for municipal income, but these were generally not statistically significant. The national economic variables remain statistically significant in all equations and have the expected signs. $^{17}$

Martins and Veiga (2013) show that regional/municipal economic variables have a quadratic effect on turnout at Portuguese elections. Their result is consistent with expressive voting (see Hillman 2010), in the sense that voters may feel more compelled to express their satisfaction/dissatisfaction at the ballot box when the economy is unusually good/bad than when economic performance is as usual. In order to take this evidence of non-linear effects into account, we introduced a quadratic term for the regional/municipal economic variables in the estimations of Table 6.

\section{[INSERT TABLE 6 ABOUT HERE]}

The results of estimation 1 clearly indicate that regional unemployment has a $\mathrm{U}$ shaped relationship with turnout. This implies that voters are more mobilized when the economy is behaving very well or very bad, but they demobilize at intermediate rates of

\footnotetext{
${ }^{16}$ The estimated marginal effects of PS Government on the government vote shares (GV) are:

- Estimation 1: $1.949 * * *(p-v a l u e=0.003)$.

- Estimation 2: $5.320 * * *$ ( $p$-value $=0.000)$.

${ }^{17}$ The estimations include all the control variables of Tables 3 and 4 . The results for those variables were not included in order to keep the Table within a reasonable size, but they are available upon request. The same procedure was adopted in the following tables.
} 
unemployment (the turning point is at $6 \%$ ). The other variables, which proxy municipal income, have the expected inverted U-shaped relationship with turnout, as greater values imply better economic outcomes. ${ }^{18}$

In the estimations of Table 7, we add the interaction of turnout in the vote equation with the dummy variable for left-wing (PS) governments. Again, only right-wing governments (PSD) lose vote shares when turnout is higher, while left-wing ones are not affected by turnout rates, providing further support for scenario 2 of Table 1 (the average marginal effects of turnout on the government vote shares are reported in the Appendix). The evidence regarding the quadratic effects of regional/municipal economic variables on turnout remains. Although most of these variables do not seem to affect vote shares directly (with the exception of the NUTS III unemployment rate), they affect it indirectly, through turnout.

[INSERT TABLE 7 ABOUT HERE]

\section{Conclusion}

Using an extensive panel dataset covering all (278) Portuguese mainland municipalities, over the period 1979-2005, which covers 10 elections, we investigated whether voter turnout affects the vote shares of incumbent governments. More concretely, we performed Three-Stage Least Squares (3SLS) estimations of a system of three simultaneous equations, whose dependent variables were, respectively, the vote share received by the incumbent government (by the party of the prime minister), the turnout rate, and the win margin (closeness of the elections).

Regarding the turnout effects, the empirical results show that, on average, higher turnout leads to lower vote shares for the incumbent government. When partisan considerations are taken into account, there is evidence that right-wing incumbents lose support when turnout is higher, while the vote shares of left-wing governments do not seem to be affected by turnout. Thus, there is some evidence of the competition effect of

\footnotetext{
${ }^{18}$ An exception to these quadratic effects of regional variables is real GDP per capita at the NUTS III level, which does not seem to affect turnout. The lack of results may eventually be due to the fact that many values of this series were generated by an interpolation algorithm, as actual values were not available for several years in our sample.
} 
turnout and of partisan bias. In this last case, then nonvoters may be less ideologically driven and more concerned with the position of each party with respect to power.

There is also empirical support for the responsibility hypothesis, as vote shares tend to increase with faster GDP growth and decrease with higher rates of inflation and unemployment. As in Veiga and Veiga (2010), the evidence of the effects of economic variables on votes is stronger for national variables than for local ones. This is not strange, as in legislative elections voters are evaluating the national government, which should be held more responsible for the national economy than for the local one.

Finally, there is clear evidence that turnout is affected by economic variables. In line with Martins and Veiga (2013), national macroeconomic variables have a linear effect on turnout, which increases when economic performance worsens, and regional/municipal economic variables have non-linear effects. Moreover, turnout is higher in extreme situations, in which economic performance is really good or bad, and lower for intermediate values of regional/municipal economic variables.

\section{Acknowledgments}

The authors thank Henry Chappell, Linda Veiga and Luís Aguiar-Conraria for very useful comments. Francisco Veiga is also thankful for the financial support provided by ERDF funds through the Operational Program Factors of Competitiveness -COMPETE and by national funds through the Portuguese Foundation for Science and Technology (FCT) under research grants PTDC/EGE-ECO/118501/2010 and PEst-C/EGE/UI3182/2011. 


\section{References}

Bengtsson, A. (2004). Economic Voting: The Effect of Political Context, Volatility and Turnout on Voters Assignment of Responsibility. European Journal of Political Research, 43: 74967.

Blais, A. (2000). To Vote or Not to Vote: The merits and Limits of Rational Choice Theory. Pittsburgh: University of Pittsburgh Press.

Blais, A. (2006). What Affects Voter Turnout? Annual Review of Political Science, 9: 111-25.

Bohrer, R., Pacek, A. and Radcliff, B. (2000). Electoral Participation, Ideology, and Party Politics in Post-communist Europe. Journal of Politics 62: 1161-72.

De Nardo, J. (1980). Turnout and the Vote: The Joke's on the Democrats. American Political Science Review 74(2): 406-20.

Downs, A. (1957). An Economic Theory of Democracy. New York: Harper Collins Publishers.

Franklin, M. (2004). Voter Turnout and the Dynamics of Electoral Competition in Established Democracies Since 1945. New York: Cambridge University Press.

Geys, B. (2006). Explaining voter turnout: A review of aggregate-level research. Electoral Studies, 25: 637-663.

Greene, W.H. (2012). Econometric Analysis, $7^{\text {th }}$ edition, Upper Saddle River, NJ: Prentice Hall.

Grofman, B., Owen, G. and Collet, G. (1999). Rethinking the Partisan Effects of Higher Turnout: So What's the Question? Public Choice 99(3): 357-76.

Hillman, A.L. (2010). Expressive behavior in economics and politics. European Journal of Political Economy, 26, 403-418.

Honaker, J. and King, G. (2010). What to do about missing values in time series cross-section data. American Journal of Political Science, 54(2): 561-581.

Hortala-Vallve, R. and Esteve-Volart, B. (2011), Voter turnout and electoral competition in a multidimensional policy space. European Journal of Political Economy 27(2), 376-384.

Jackman, R. (1987). Political Institutions and Voter Turnout in the Industrial Democracies. American Journal of Political Science, 37: 405-23.

Jackman, R. and Miller, R. (1995). Voter Turnout in the Industrial Democracies During the 1980s. Comparative Political Studies, 27(4): 467-469. 
Lacy, D. and Burden B. (1999). The Vote-Stealing and Turnout Effects of Ross Perot in the 1992 U.S. Presidential Election, American Journal of Political Science, 43(1): 233-55.

Lau, R. (1982). Negativity in Political Perceptions. Political Behavior 4: 353-78.

Laakso, M. and Taegepera, R. (1979). The effective number of parties: A measure with application to Western Europe. Comparative Political Studies, 12(1): 3-27.

Levernier, W. (1992). A two-stage model of the effect of economic conditions on election outcomes. Atlantic Economic Journal, 20(2): 189-96.

Lijphart, A. (1997). Unequal Participation: Democracy's Unresolved Dilemma. American Political Science Review, 91(1): 1-14.

Lutz, G. and Marsh, M. (2007). Introduction: Consequences of Low Turnout. Electoral Studies, 26: 539-47.

Martins, R. and Veiga F.J. (2013). Economic performance and turnout at national and local elections. Forthcoming in Public Choice. DOI: 10.1007/s11127-012-0047-5.

Nannestad, P. and Paldam, M. (1994). The VP-function: A Survey of the Literature on Vote and Popularity After 25 Years. Public Choice, 79: 213-45.

Pacek, A. and Radcliff, B. (1995). Turnout and the Vote for Left-of-Centre Parties: A CrossNational Analysis. British Journal of Political Science 24: 137-43.

Paldam, M. (2004). Are Vote and Popularity Functions Economically Correct?, in C.K. Rowley \& F. Schneider (Eds.), The Encyclopedia of Public Choice (pp. 49-59). Netherlands: Kluwer Academic.

Riker, W. and Ordeshook, P. (1968). A Theory of the Calculus of Voting. American Political Science Review 62:1: 25-42.

Tucker, H.J. and Vedlitz, A. (1986). Does heavy Turnout Help Democrats in Presidential Elections?. American Political Science Review, 80: 1291-98.

Veiga, F.j. and Veiga, L.G. (2010). "The Impact of Local and National Conditions on Legislative Elections Results." Applied Economics 42: 1727-34.

Zellner, A. and Theil, H. (1962). "Three stage least squares: Simultaneous estimation of simultaneous equations." Econometrica 30(1), 54-78.

Zimmer, T. A. (1985). Political Competition, Voter Turnout and Party Vote. Social Science Journal, 22: 103-10. 
Table 1. Scenarios and conclusions for the effect of turnout variations

\begin{tabular}{c|l|l|}
\hline \hline & \multicolumn{1}{|c|}{$\begin{array}{c}\text { Effect of turnout variations } \\
\text { on government VP function }\end{array}$} & \multicolumn{1}{c|}{ Theoretical conclusion } \\
\hline \hline$(1)$ & $\begin{array}{l}\bullet \text { RIGHT: negative effect } \\
\text { - LEFT: negative effect } \\
\text { The right is more penalized than } \\
\text { the left. }\end{array}$ & $\begin{array}{l}\text { Strong dominance of the competition effect. } \\
\text { Weak evidence of partisan bias. }\end{array}$ \\
\hline$(2)$ & $\begin{array}{l}\bullet \text { RIGHT: negative effect } \\
\text { LEFT: no effect }\end{array}$ & $\begin{array}{l}\text { Some evidence of the competition effect. } \\
\text { Some evidence of partisan bias. }\end{array}$ \\
\hline$(3)$ & $\begin{array}{l}\text { RIGHT: negative effect } \\
\text { - LEFT: positive effect }\end{array}$ & $\begin{array}{l}\text { Strong evidence of partisan bias. } \\
\text { Weak dominance of the competition effect. }\end{array}$ \\
\hline$(4)$ & $\begin{array}{l}\bullet \text { RIGHT: no effect } \\
\bullet \text { LEFT: positive effect }\end{array}$ & $\begin{array}{l}\text { No evidence of the competition effect. } \\
\text { Partisan bias with asymmetric response. }\end{array}$ \\
\hline \hline
\end{tabular}


Table 2: Descriptive Statistics

\begin{tabular}{lrrrrr}
\hline Variable & \# Obs. & Mean & Std.Dev. & Min. & Max. \\
\hline Effective number of parties (district) & 2477 & 3.19 & 0.65 & 2.04 & 5.08 \\
Election & 2477 & 7.01 & 2.58 & 3.00 & 11.00 \\
Fiscal burden index (ybe) & 1103 & 3.63 & 14.14 & 0.04 & 252.27 \\
Government share of votes & 2477 & 38.75 & 16.03 & 5.45 & 85.45 \\
Growth rate of wages (ybe) & 1653 & 3.03 & 5.18 & -24.80 & 59.54 \\
Income index (ybe) & 1103 & 3.63 & 11.71 & 0.19 & 193.29 \\
PS Government & 2477 & 0.33 & 0.47 & 0.00 & 1.00 \\
National inflation rate (ybe) & 2477 & 12.79 & 9.49 & 2.36 & 28.88 \\
National real GDP growth rate (ybe) & 2477 & 2.59 & 2.18 & -1.88 & 5.64 \\
National unemployment rate (ybe) & 2477 & 6.63 & 1.59 & 4.07 & 8.86 \\
NUTS III real GDP growth rate (ybe) & 1103 & 3.28 & 3.27 & -5.46 & 25.35 \\
NUTS III unemployment rate (ybe) & 1103 & 5.80 & 2.41 & 1.67 & 13.54 \\
Population density & 2477 & 2.83 & 8.76 & 0.06 & 96.36 \\
\% Population in tertiary sector & 2474 & 43.39 & 15.27 & 10.07 & 85.57 \\
\% Population over 65 years old & 2477 & 17.80 & 6.00 & 5.33 & 42.02 \\
Sales index (ybe) & 1103 & 3.63 & 10.40 & 0.19 & 168.79 \\
Same party as national & 2477 & 0.41 & 0.49 & 0.00 & 1.00 \\
Turnout & 2477 & 69.28 & 8.88 & 48.07 & 92.67 \\
Winning margin (district) & 2477 & 16.42 & 11.60 & 0.05 & 45.82 \\
Winning margin (municipality) & 2477 & 20.12 & 15.04 & 0.01 & 77.20 \\
\hline SOurCes: CNE, DGAL, IIF, INE, OECD & Marktest & MSSS. & & &
\end{tabular}

Sources: CNE, DGAL, IMF, INE, OECD, Marktest, MSSS.

Note: "ybe" stands for year before election. 
Table 3: Votes, turnout and the national economy

\begin{tabular}{|c|c|c|c|c|c|c|}
\hline & \multicolumn{2}{|c|}{ (1) } & \multicolumn{4}{|c|}{ (2) } \\
\hline & Vote share & Turnout & Win Margin & Vote share & Turnout & Win Margin \\
\hline Turnout & $\begin{array}{c}-0.429 * * * \\
(-7.907)\end{array}$ & & & $\begin{array}{c}-0.729 * * * \\
(-14.35)\end{array}$ & & \\
\hline $\begin{array}{l}\text { National unemploy- } \\
\text { ment rate (ybe) }\end{array}$ & $\begin{array}{c}-1.689 * * * \\
(-10.10)\end{array}$ & $\begin{array}{c}1.548 * * * \\
(13.66)\end{array}$ & & & & \\
\hline $\begin{array}{l}\text { National inflation } \\
\text { rate (ybe) }\end{array}$ & $\begin{array}{c}-1.350 * * * \\
(-29.64)\end{array}$ & $\begin{array}{c}0.578 * * * \\
(14.19)\end{array}$ & & $\begin{array}{c}-0.286^{* * *} \\
(-4.508)\end{array}$ & $\begin{array}{c}0.0497^{*} \\
(1.674)\end{array}$ & \\
\hline $\begin{array}{l}\text { National real GDP } \\
\text { growth rate (ybe) }\end{array}$ & & & & $\begin{array}{c}2.941 * * * \\
(23.22)\end{array}$ & $\begin{array}{c}-0.836 * * * \\
(-17.04)\end{array}$ & \\
\hline $\begin{array}{l}\text { Government share } \\
\text { of votes }(-1)\end{array}$ & $\begin{array}{c}-0.145^{* * *} \\
(-8.994)\end{array}$ & & & $\begin{array}{c}-0.0280^{* *} \\
(-2.006)\end{array}$ & & \\
\hline $\begin{array}{l}\text { Government share } \\
\text { of votes }(-2)\end{array}$ & $\begin{array}{c}-0.321 * * * \\
(-21.29)\end{array}$ & & & $\begin{array}{c}-0.272^{* * *} \\
(-19.41)\end{array}$ & & \\
\hline Turnout $(-1)$ & & $\begin{array}{c}0.830 * * * \\
(58.86)\end{array}$ & & & $\begin{array}{c}0.952^{* * *} \\
(51.71)\end{array}$ & \\
\hline Population density & $\begin{array}{c}-0.0328 * * * \\
(-3.577)\end{array}$ & $\begin{array}{c}-0.0102 * * * \\
(-3.160)\end{array}$ & & $\begin{array}{c}-0.0307 * * * \\
(-3.586)\end{array}$ & $\begin{array}{c}-0.0113 * * * \\
(-2.672)\end{array}$ & \\
\hline $\begin{array}{l}\text { Same party as } \\
\text { national }\end{array}$ & $\begin{array}{c}5.399 * * * \\
(13.95)\end{array}$ & $\begin{array}{c}0.209 * * \\
(2.063)\end{array}$ & & $\begin{array}{c}4.519 * * * \\
(12.47)\end{array}$ & $\begin{array}{l}0.0147 \\
(0.111)\end{array}$ & \\
\hline $\begin{array}{l}\text { \% Population over } \\
65 \text { years old }\end{array}$ & & $\begin{array}{l}-0.00917 \\
(-0.586)\end{array}$ & & & $\begin{array}{l}0.0237 \\
(1.142)\end{array}$ & \\
\hline $\begin{array}{l}\% \text { Population in } \\
\text { tertiary sector }\end{array}$ & & $\begin{array}{c}0.0186 * * * \\
(3.617)\end{array}$ & & & $\begin{array}{c}0.0224 * * * \\
(3.298)\end{array}$ & \\
\hline $\begin{array}{l}\text { Winning margin } \\
\text { (district) }\end{array}$ & & $\begin{array}{c}-0.0785 * * * \\
(-2.629)\end{array}$ & & & $\begin{array}{c}0.366 * * * \\
(17.41)\end{array}$ & \\
\hline $\begin{array}{l}\text { Effective number of } \\
\text { parties (district) }\end{array}$ & & $\begin{array}{c}-5.745^{* * *} \\
(-9.640)\end{array}$ & & & $\begin{array}{c}-0.346 \\
(-0.979)\end{array}$ & \\
\hline $\begin{array}{l}\text { Winning margin } \\
\text { (district) }(-1)\end{array}$ & & & $\begin{array}{c}-0.124 * * * \\
(-5.616)\end{array}$ & & & $\begin{array}{c}-0.101 * * * \\
(-4.970)\end{array}$ \\
\hline $\begin{array}{l}\text { Winning margin } \\
\qquad \text { (municipal) }(-1)\end{array}$ & & & $\begin{array}{c}-0.175^{* * *} \\
(-9.497)\end{array}$ & & & $\begin{array}{c}-0.193 * * * \\
(-11.75)\end{array}$ \\
\hline $\begin{array}{l}\text { Government share } \\
\text { of votes }\end{array}$ & & & $\begin{array}{c}0.511^{* * *} \\
(25.03)\end{array}$ & & & $\begin{array}{c}0.442 * * * \\
(23.21)\end{array}$ \\
\hline Election (time) & $\begin{array}{c}-5.774 * * * \\
(-28.28)\end{array}$ & $\begin{array}{c}2.137 * * * \\
(16.82)\end{array}$ & $\begin{array}{c}-0.736^{* * *} \\
(-10.10)\end{array}$ & $\begin{array}{c}-2.396 * * * \\
(-9.645)\end{array}$ & $\begin{array}{c}0.677^{* * *} \\
(6.456)\end{array}$ & $\begin{array}{c}-0.735 * * * \\
(-10.21)\end{array}$ \\
\hline \# Observations & 2,474 & 2,474 & 2,474 & 2,474 & 2,474 & 2,474 \\
\hline Adjusted R-squared & 0.576 & 0.932 & 0.210 & 0.635 & 0.791 & 0.232 \\
\hline
\end{tabular}

NOTES: Three-stage least squares (3SLS) results using robust standard errors weighted by the number of registered voters in each municipality. The results for the winning margin equation are not shown here but are available upon request. All estimations include a constant and a complete set of district dummies. ${ }^{* * *} \mathrm{p}<0.01,{ }^{* *} \mathrm{p}<0.05,{ }^{*} \mathrm{p}<0.1$. Numbers in parenthesis are t-ratios. "ybe" stands for year before election. 
Table 4: Effects of turnout depending on the government party

\begin{tabular}{|c|c|c|c|c|}
\hline & \multicolumn{2}{|c|}{ (1) } & \multicolumn{2}{|c|}{ (2) } \\
\hline & Vote share & Turnout & Vote share & Turnout \\
\hline Turnout & $\begin{array}{c}-0.666 * * * \\
(-10.40)\end{array}$ & & $\begin{array}{c}-1.062^{* * *} \\
(-18.29)\end{array}$ & \\
\hline PS Government & $\begin{array}{c}-41.15^{* * *} \\
(-8.445)\end{array}$ & & $\begin{array}{c}-75.16^{* * *} \\
(-17.47)\end{array}$ & \\
\hline $\begin{array}{l}\text { Turnout * PS } \\
\text { Government }\end{array}$ & $\begin{array}{c}0.611^{* * *} \\
(8.558) \\
\end{array}$ & & $\begin{array}{c}1.141^{* * *} \\
(17.65) \\
\end{array}$ & \\
\hline $\begin{array}{l}\text { National unemployment } \\
\text { rate (ybe) }\end{array}$ & $\begin{array}{c}-2.423^{* * *} \\
(-11.05)\end{array}$ & $\begin{array}{c}1.604^{* * *} \\
(15.82)\end{array}$ & & \\
\hline $\begin{array}{l}\text { National inflation } \\
\text { rate (ybe) }\end{array}$ & $\begin{array}{c}-1.641 * * * \\
(-24.85)\end{array}$ & $\begin{array}{c}0.573 * * * \\
(15.60)\end{array}$ & $\begin{array}{c}-0.579 * * * \\
(-8.108)\end{array}$ & $\begin{array}{l}-0.0285 \\
(-0.973)\end{array}$ \\
\hline $\begin{array}{l}\text { National real GDP } \\
\text { growth rate (ybe) }\end{array}$ & & & $\begin{array}{c}3.992 * * * \\
(28.83) \\
\end{array}$ & $\begin{array}{c}-0.817 * * * \\
(-15.91) \\
\end{array}$ \\
\hline $\begin{array}{l}\text { Government share of } \\
\text { votes }(-1)\end{array}$ & $\begin{array}{c}-0.169 * * * \\
(-8.582)\end{array}$ & & $\begin{array}{l}0.0223 \\
(1.543)\end{array}$ & \\
\hline $\begin{array}{l}\text { Government share of } \\
\text { votes }(-2)\end{array}$ & $\begin{array}{c}-0.321 * * * \\
(-18.74)\end{array}$ & & $\begin{array}{c}-0.284^{* * *} \\
(-19.91)\end{array}$ & \\
\hline Turnout (-1) & & $\begin{array}{c}0.820 * * * \\
(58.95)\end{array}$ & & $\begin{array}{c}0.963 * * * \\
(50.35)\end{array}$ \\
\hline Population density & $\begin{array}{c}-0.0340 * * * \\
(-3.752)\end{array}$ & $\begin{array}{c}-0.0102 * * * \\
(-3.202)\end{array}$ & $\begin{array}{c}-0.0300 * * * \\
(-3.656)\end{array}$ & $\begin{array}{c}-0.0137 * * * \\
(-3.103)\end{array}$ \\
\hline Same party as national & $\begin{array}{c}5.774 * * * \\
(14.99)\end{array}$ & $\begin{array}{c}0.358 * * * \\
(3.611)\end{array}$ & $\begin{array}{c}4.687^{* * *} \\
(13.50)\end{array}$ & $\begin{array}{l}-0.127 \\
(-0.934)\end{array}$ \\
\hline $\begin{array}{l}\% \text { Population over } 65 \\
\text { years old }\end{array}$ & & $\begin{array}{l}-0.0163 \\
(-1.052)\end{array}$ & & $\begin{array}{l}0.0349 \\
(1.624)\end{array}$ \\
\hline $\begin{array}{l}\text { \% Population in tertiary } \\
\text { sector }\end{array}$ & & $\begin{array}{c}0.0186 * * * \\
(3.643)\end{array}$ & & $\begin{array}{c}0.0281^{* * *} \\
(3.996)\end{array}$ \\
\hline $\begin{array}{l}\text { Winning margin } \\
\quad \text { (district) }\end{array}$ & & $\begin{array}{l}-0.151^{* * *} \\
(-5.749)\end{array}$ & & $\begin{array}{c}0.484^{* * *} \\
(26.14)\end{array}$ \\
\hline $\begin{array}{r}\text { Effective number of } \\
\text { parties (district) }\end{array}$ & & $\begin{array}{c}-6.209 * * * \\
(-11.74)\end{array}$ & & $\begin{array}{c}0.970 * * * \\
(2.940)\end{array}$ \\
\hline Election (time) & $\begin{array}{c}-7.166^{* * *} \\
(-28.62) \\
\end{array}$ & $\begin{array}{c}2.047^{* * *} \\
(17.47) \\
\end{array}$ & $\begin{array}{c}-3.467^{* * *} \\
(-13.83) \\
\end{array}$ & $\begin{array}{c}0.567^{* * *} \\
(5.258)\end{array}$ \\
\hline \# Observations & 2,474 & 2,474 & 2,474 & 2,474 \\
\hline Adjusted R-squared & 0.589 & 0.932 & 0.666 & 0.707 \\
\hline
\end{tabular}

NOTES: Three-stage least squares (3SLS) results using robust standard errors weighted by the number of registered voters in each municipality. The results for the winning margin equation are not shown here but are available upon request. All estimations include a constant and a complete set of district dummies. ${ }^{* * *} \mathrm{p}<0.01,{ }^{* *} \mathrm{p}<0.05,{ }^{*} \mathrm{p}<0.1$. Numbers in parenthesis are t-ratios. "ybe" stands for year before election. 
Table 5: Votes, turnout and the regional/local economy

\begin{tabular}{|c|c|c|c|c|c|c|c|c|}
\hline & \multicolumn{2}{|c|}{ (1) } & \multicolumn{2}{|c|}{ (2) } & \multicolumn{2}{|c|}{ (3) } & \multicolumn{2}{|c|}{ (4) } \\
\hline & Vote share & Turnout & Vote share & Turnout & Vote share & Turnout & Vote share & Turnout \\
\hline Turnout & $\begin{array}{c}-0.243 * * * \\
(-3.208)\end{array}$ & & $\begin{array}{c}-0.318 * * * \\
(-4.856)\end{array}$ & & $\begin{array}{c}-0.309 * * * \\
(-4.673)\end{array}$ & & $\begin{array}{c}-0.306 * * * \\
(-4.622)\end{array}$ & \\
\hline $\begin{array}{l}\text { National unemployment } \\
\text { rate (ybe) }\end{array}$ & $\begin{array}{c}-2.379 * * * \\
(-7.348)\end{array}$ & $\begin{array}{c}1.764^{* * *} \\
(18.22)\end{array}$ & & & & & & \\
\hline $\begin{array}{l}\text { National real GDP growth } \\
\text { rate (ybe) }\end{array}$ & & & $\begin{array}{c}3.929 * * * \\
(19.85)\end{array}$ & $\begin{array}{c}-1.373 * * * \\
(-39.22)\end{array}$ & $\begin{array}{c}4.060 * * * \\
(20.97)\end{array}$ & $\begin{array}{c}-1.368 * * * \\
(-42.66)\end{array}$ & $\begin{array}{c}4.072 * * * \\
(20.99)\end{array}$ & $\begin{array}{c}-1.369 * * * \\
(-42.67)\end{array}$ \\
\hline $\begin{array}{l}\text { NUTS III unemployment } \\
\text { rate (ybe) }\end{array}$ & $\begin{array}{c}-0.843 * * * \\
(-4.348)\end{array}$ & $\begin{array}{l}0.115^{*} \\
(1.839)\end{array}$ & & & & & & \\
\hline $\begin{array}{l}\text { NUTS III real GDP growth } \\
\text { rate (ybe) }\end{array}$ & & & $\begin{array}{l}0.213^{* *} \\
(2.393)\end{array}$ & $\begin{array}{c}0.00786 \\
(0.387)\end{array}$ & & & & \\
\hline Income index (ybe) & & & & & $\begin{array}{l}0.0116 \\
(1.496)\end{array}$ & $\begin{array}{c}0.000489 \\
(0.261)\end{array}$ & & \\
\hline Fiscal burden index (ybe) & & & & & & & $\begin{array}{l}0.0119 * \\
(1.854)\end{array}$ & $\begin{array}{c}-0.00146 \\
(-0.943)\end{array}$ \\
\hline \# Observations & 1,100 & 1,100 & 1,100 & 1,100 & 1,100 & 1,100 & 1,100 & 1,100 \\
\hline Adjusted R-squared & 0.460 & 0.760 & 0.589 & 0.886 & 0.586 & 0.886 & 0.587 & 0.886 \\
\hline
\end{tabular}

NOTES: Three-stage least squares (3SLS) results using robust standard errors weighted by the number of registered voters in each municipality. The results for the winning margin equation are not shown here but are available upon request. All estimations include the control variables shown in Tables 3 and 4 , a constant and a complete set of district dummies. ${ }^{* * *} p<0.01,{ }^{* *} p<0.05,{ }^{*} p<0.1$. Numbers in parenthesis are t-ratios. "ybe" stands for year before election. 
Table 6: Votes, turnout and quadratic effects of the regional/local economy on turnout

\begin{tabular}{|c|c|c|c|c|c|c|c|c|}
\hline & \multicolumn{2}{|c|}{ (1) } & \multicolumn{2}{|c|}{ (2) } & \multicolumn{2}{|c|}{ (3) } & \multicolumn{2}{|c|}{ (4) } \\
\hline & Vote share & Turnout & Vote share & Turnout & Vote share & Turnout & Vote share & Turnout \\
\hline Turnout & $\begin{array}{c}-0.353^{* * *} \\
(-4.663)\end{array}$ & & $\begin{array}{c}-0.315^{* * *} \\
(-4.772)\end{array}$ & & $\begin{array}{c}-0.317^{* * *} \\
(-4.814)\end{array}$ & & $\begin{array}{c}-0.311^{* * *} \\
(-4.708)\end{array}$ & \\
\hline $\begin{array}{l}\text { National unemployment } \\
\text { rate (ybe) }\end{array}$ & $\begin{array}{c}-2.225^{* * *} \\
(-6.859)\end{array}$ & $\begin{array}{c}1.839 * * * \\
(19.26)\end{array}$ & & & & & & \\
\hline $\begin{array}{l}\text { National real GDP growth } \\
\text { rate (ybe) }\end{array}$ & & & $\begin{array}{c}4.048 * * * \\
(20.91)\end{array}$ & $\begin{array}{c}-1.373 * * * \\
(-42.90)\end{array}$ & $\begin{array}{c}4.044 * * * \\
(20.89)\end{array}$ & $\begin{array}{c}-1.372 * * * \\
(-42.90)\end{array}$ & $\begin{array}{c}4.063 * * * \\
(20.94)\end{array}$ & $\begin{array}{c}-1.381 * * * \\
(-43.14)\end{array}$ \\
\hline $\begin{array}{l}\text { NUTS III unemployment } \\
\text { rate (ybe) }\end{array}$ & $\begin{array}{c}-0.855^{* * *} \\
(-4.390)\end{array}$ & $\begin{array}{c}-1.102^{* * *} \\
(-5.963)\end{array}$ & & & & & & \\
\hline $\begin{array}{l}\text { NUTS III unemployment } \\
\text { rate (ybe) squared }\end{array}$ & & $\begin{array}{c}0.0904^{* * *} \\
(6.955)\end{array}$ & & & & & & \\
\hline Income index (ybe) & & & $\begin{array}{l}0.0115 \\
(1.488)\end{array}$ & $\begin{array}{c}0.0256^{* * *} \\
(3.096)\end{array}$ & & & & \\
\hline $\begin{array}{l}\text { Income index (ybe) } \\
\text { squared }\end{array}$ & & & & $\begin{array}{c}-0.000124^{* * *} \\
(-3.115)\end{array}$ & & & & \\
\hline Sales index (ybe) & & & & & $\begin{array}{l}0.0124 \\
(1.364)\end{array}$ & $\begin{array}{c}0.0281^{* * *} \\
(3.163)\end{array}$ & & \\
\hline Sales index (ybe) squared & & & & & & $\begin{array}{c}-0.000156 * * * \\
(-3.194)\end{array}$ & & \\
\hline Fiscal burden index (ybe) & & & & & & & $\begin{array}{l}0.0119 * \\
(1.847)\end{array}$ & $\begin{array}{c}0.0242 * * * \\
(4.068)\end{array}$ \\
\hline $\begin{array}{c}\text { Fiscal burden index } \\
\text { squared (ybe) }\end{array}$ & & & & & & & & $\begin{array}{c}-0.0001^{* * *} \\
(-4.460)\end{array}$ \\
\hline \# Observations & 1,100 & 1,100 & 1,100 & 1,100 & 1,100 & 1,100 & 1,100 & 1,100 \\
\hline Adjusted R-squared & 0.476 & 0.768 & 0.587 & 0.886 & 0.587 & 0.886 & 0.587 & 0.887 \\
\hline
\end{tabular}

NOTES: Three-stage least squares (3SLS) results using robust standard errors weighted by the number of registered voters in each municipality. The results for the winning margin equation are not shown here but are available upon request. All estimations include the control variables shown in Tables 3 and 4 , a constant and a complete set of district dummies. ${ }^{* * *} \mathrm{p}<0.01,{ }^{* *} \mathrm{p}<0.05, * \mathrm{p}<0.1$. Numbers in parenthesis are t-ratios. "ybe" stands for year before election. 
Table 7: Votes, turnout and quadratic effects of the regional/local economy on turnout

\begin{tabular}{|c|c|c|c|c|c|c|c|c|}
\hline & \multicolumn{2}{|c|}{ (1) } & \multicolumn{2}{|c|}{ (2) } & \multicolumn{2}{|c|}{ (3) } & \multicolumn{2}{|c|}{ (4) } \\
\hline & Vote share & Turnout & Vote share & Turnout & Vote share & Turnout & Vote share & Turnout \\
\hline Turnout & $-0.511 * * *$ & & $\begin{array}{c}-0.701 * * * \\
-8\end{array}$ & & $\begin{array}{c}-0.703 * * * \\
(-8539)\end{array}$ & & $\begin{array}{c}-0.699 * * * \\
(-8)\end{array}$ & \\
\hline PS Government & $\begin{array}{l}2.785 \\
(0.442)\end{array}$ & & $\begin{array}{c}-45.07^{* * *} \\
(-7.683)\end{array}$ & & $\begin{array}{c}-45.10^{* * *} \\
(-7.684)\end{array}$ & & $\begin{array}{c}-45.21^{* * *} \\
(-7.705)\end{array}$ & \\
\hline Turnout * PS Government & $\begin{array}{c}0.467 * * * \\
(5.208)\end{array}$ & & $\begin{array}{c}0.681^{* * *} \\
(7.526)\end{array}$ & & $\begin{array}{c}0.681^{* * *} \\
(7.528)\end{array}$ & & $\begin{array}{c}0.682^{* * *} \\
(7.545)\end{array}$ & \\
\hline $\begin{array}{l}\text { National unemployment } \\
\text { rate (ybe) }\end{array}$ & $\begin{array}{c}12.26 * * * \\
(12.65)\end{array}$ & $\begin{array}{c}1.867^{* * *} \\
(19.64)\end{array}$ & & & & & & \\
\hline $\begin{array}{l}\text { National real GDP growth } \\
\text { rate (ybe) }\end{array}$ & & & $\begin{array}{c}4.368^{* * *} \\
(13.69)\end{array}$ & $\begin{array}{c}-1.384 * * * \\
(-43.73)\end{array}$ & $\begin{array}{c}4.363^{* * *} \\
(13.68)\end{array}$ & $\begin{array}{c}-1.384 * * * \\
(-43.73)\end{array}$ & $\begin{array}{c}4.386 * * * \\
(13.73)\end{array}$ & $\begin{array}{c}-1.392 * * * \\
(-44.00)\end{array}$ \\
\hline $\begin{array}{l}\text { NUTS III unemployment } \\
\text { rate (ybe) }\end{array}$ & $\begin{array}{c}-0.986 * * * \\
(-5.713)\end{array}$ & $\begin{array}{c}-1.471 * * * \\
(-7.721)\end{array}$ & & & & & & \\
\hline $\begin{array}{l}\text { NUTS III unemployment } \\
\text { rate (ybe) squared }\end{array}$ & & $\begin{array}{c}0.117^{* * *} \\
(8.709)\end{array}$ & & & & & & \\
\hline Income index (ybe) & & & $\begin{array}{c}0.00849 \\
(1.124)\end{array}$ & $\begin{array}{c}0.0263 * * * \\
(3.167)\end{array}$ & & & & \\
\hline Income index (ybe) squared & & & & $\begin{array}{c}-0.0001 * * * \\
(-3.177)\end{array}$ & & & & \\
\hline Sales index (ybe) & & & & & $\begin{array}{c}0.00885 \\
(1.000)\end{array}$ & $\begin{array}{c}0.0289 * * * \\
(3.221)\end{array}$ & & \\
\hline Sales index (ybe) squared & & & & & & $\begin{array}{c}-0.00016^{* * *} \\
(-3.243)\end{array}$ & & \\
\hline Fiscal burden index (ybe) & & & & & & & $\begin{array}{c}0.00871 \\
(1.389)\end{array}$ & $\begin{array}{c}0.0250^{* * *} \\
(4.173)\end{array}$ \\
\hline Fiscal burden index (ybe) & & & & & & & & $\begin{array}{c}-0.0001 * * * \\
(-4.557)\end{array}$ \\
\hline \# Observations & 1,100 & 1,100 & 1,100 & 1,100 & 1,100 & 1,100 & 1,100 & 1,100 \\
\hline Adjusted R-squared & 0.606 & 0.782 & 0.606 & 0.891 & 0.606 & 0.891 & 0.607 & 0.891 \\
\hline
\end{tabular}

NOTES: Three-stage least squares (3SLS) results using robust standard errors weighted by the number of registered voters in each municipality. The results for the winning margin equation are not shown here but are available upon request. All estimations include the control variables shown in Tables 3 and 4 , a constant and a complete set of district dummies. $* * * p<0.01, * * p<0.05, * p<0.1$. Numbers in parenthesis are $t$-ratios. "ybe" stands for year before election. 


\section{Appendix 1}

Table A.1: Estimated Marginal Effects of Turnout on Vote Shares

\begin{tabular}{cccc}
\hline Table & Estimation & $\begin{array}{c}\text { Right-wing (PS) Government } \\
\text { (PS Government=0) }\end{array}$ & $\begin{array}{c}\text { Left-wing Government } \\
\text { (PS Government=1) }\end{array}$ \\
\hline \multirow{2}{*}{4} & 1 & $-0.665^{* * *}$ & -0.054 \\
& 2 & $-1.062^{* * *}$ & 0.079 \\
\hline \multirow{3}{*}{7} & 1 & $-0.511^{* * *}$ & -0.043 \\
& 2 & $-0.693^{* * *}$ & -0.024 \\
& 3 & $-0.701^{* * *}$ & -0.020 \\
& 4 & $-0.703^{* * *}$ & -0.022 \\
\hline
\end{tabular}




\section{Most Recent Working Paper}

NIPE WP Martins, Rodrigo e Francisco José Veiga, "Does voter turnout affect the votes for the incumbent

$15 / 2013$

NIPE WP Aguiar-Conraria, Luís, Pedro C. Magalhães e Christoph A. Vanberg, "Experimental evidence

$14 / 2013$ that quorum rules discourage turnout and promote election boycotts", 2013

NIPE WP Silva, José Ferreira, J. Cadima Ribeiro, “As Assimetrias Regionais em Portugal: análise da

13/2013 convergência versus divergência ao nível dos municípios”, 2013

NIPE WP Faria, Ana Paula, Natália Barbosa e Vasco Eiriz, "Firms' innovation across regions: an

12/2013 exploratory study", 2013

NIPE WP Veiga, Francisco José, “Instituições, Estabilidade Política e Desempenho Económico

11/2013 Implicações para Portugal”, 2013

NIPE WP Barbosa, Natália, Ana Paula Faria e Vasco Eiriz, "Industry- and firm-specific factors of

10/2013 innovation novelty", 2013

NIPE WP Castro, Vítor e Megumi Kubota, "Duration dependence and change-points in the likelihood of

09/2013 credit booms ending", 2013

NIPE WP Monteiro, Natália Pimenta e Geoff Stewart "Scale, Scope and Survival: A Comparison of

$08 / 2013$

NIPE WP

$07 / 2013$

Cooperative and Capitalist Modes of Production", 2013

NIPE WP Barbosa, Natália, Maria Helena Guimarães e Ana Paula Faria, "Single Market non-

06/2013

compliance: how relevant is the institutional setting?", 2013

NIPE WP Lommerud, Kjell Erik, Odd Rune Straume e Steinar Vagstad, "Mommy tracks and public

05/2013 policy: On self-fulfilling prophecies and gender gaps in promotion”, 2013

NIPE WP Brekke, Kurt R., Luigi Siciliani e Odd Rune Straume, "Hospital Mergers: A Spatial

04/2013

NIPE WP

$03 / 2013$

NIPE WP

02/2013

NIPE WP

$01 / 2013$

Competition Approach”, 2013

Faria, Ana Paula e Natália Barbosa, “Does venture capital really foster innovation?", 2013

Esteves, Rosa Branca, “Customer Poaching with Retention Strategies”, 2013

NIPE WP

27/2012

NIPE WP

$26 / 2012$

NIPE WP

$25 / 2012$

NIPE WP

24/2012

NIPE WP

$23 / 2012$

NIPE WP

22/2012

Aguiar-Conraria, Luís, Teresa Maria Rodrigues e Maria Joana Soares, "Oil Shocks and the Euro as an Optimum Currency Area", 2013

Ricardo M. Sousa, "The Effects of Monetary Policy in a Small Open Economy: The Case of

Portugal" 2012

Sushanta K. Mallick e Ricardo M. Sousa, "Is Technology Factor-Neutral? Evidence from the US Manufacturing Sector" 2012

NIPE WP Agnello, L, Sushanta K. Mallick e Ricardo M. Sousa, "Financial Reforms and Income

21/2012 Inequality" 2012

NIPE WP Agnello, L, Gilles Dufrénot e Ricardo M. Sousa, "Adjusting the U.S. Fiscal Policy for Asset

20/2012 Prices: Evidence from a TVP-MS Framework t" 2012

NIPE WP Agnello, L e Ricardo M. Sousa, "Fiscal Adjustments and Income Inequality: A First

19/2012 Assessment" 2012

NIPE WP Agnello, L, Vitor Castro e Ricardo M. Sousa, "Are there change-points in the likelihood of a

18/2012 fiscal consolidation ending?" 2012

NIPE WP Agnello, L, Vitor Castro e Ricardo M. Sousa, "What determines the duration of a fiscal

$17 / 2012$

consolidation program?" 2012 